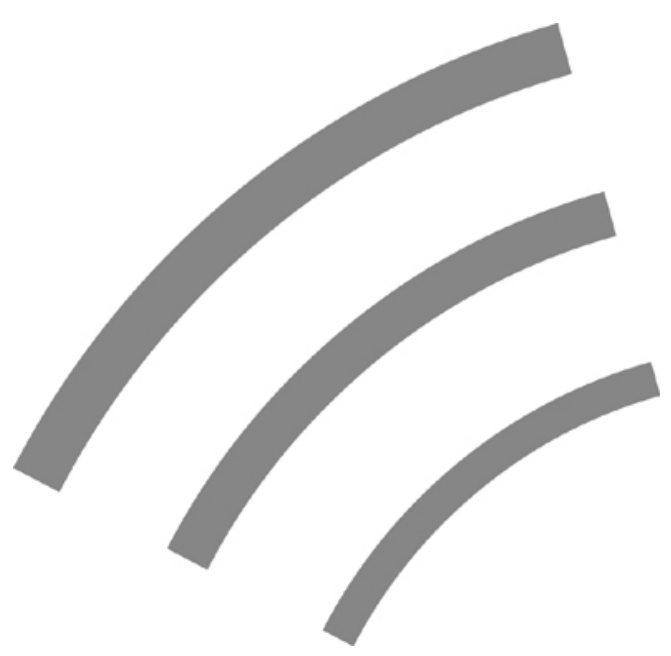

SCALES-paper N200307

\title{
Organizing Successful New Service Development: A Literature Review
}

Jeroen P.J. de Jong

Patrick A.M. Vermeulen

Zoetermeer, June $6^{\text {th }}, 2003$ 
The SCALES-paper series is an electronic working paper series of EIM Business and Policy Research. The SCALES-initiative (Scientific Analysis of Entrepreneurship and SMEs) is part of the 'SMEs and Entrepreneurship' programme, financed by the Netherlands' Ministry of Economic Affairs. Complete information on this programme can be found at www.eim.nl/smes-and-entrepreneurship

The papers in the SCALES-series report on ongoing research at EIM. The information in the papers may be (1) background material to regular EIM Research Reports, (2) papers presented at international academic conferences, (3) submissions under review at academic journals. The papers are directed at a research-oriented audience and intended to share knowledge and promote discussion on topics in the academic fields of small business economics and entrepreneurship research.

$\begin{array}{ll}\text { address: } & \text { Italiëlaan } 33 \\ \text { mail address: } & \text { P.O. Box } 7001 \\ & \text { 2701 AA Zoetermeer } \\ \text { telephone: } & +31793413634 \\ \text { telefax: } & +31793415024 \\ \text { website: } & \text { www.eim.nl }\end{array}$

The responsibility for the contents of this report lies with EIM. Quoting numbers or text in papers, essays and books is permitted only when the source is clearly mentioned. No part of this publication may be copied and/or published in any form or by any means, or stored in a retrieval system, without the prior written permission of EIM.

EIM does not accept responsibility for printing errors and/or other imperfections. 


\title{
Organizing Successful New Service Development: A Literature Review
}

\author{
Jeroen P.J. de Jong \\ EIM Small Business Research and Consultancy \\ Italielaan 33, P.O. Box 7001 \\ 2701 AA Zoetermeer \\ The Netherlands \\ E-mail: $\underline{\text { JJO@eim.nl }}$
}

And

Patrick A.M. Vermeulen'

Erasmus University Rotterdam

Rotterdam School of Management

Department of Strategy and Business Environment

FG- Building

P.O. Box 1738

3000 DR Rotterdam

The Netherlands

E-mail: $\underline{\text { P.Vermeulen@ffbk.eur.nl }}$

Paper re-submitted to Management Decision $2^{\text {nd }}$ Version, June 6th

\footnotetext{
${ }^{1}$ Please send all correspondence to the second author
} 


\title{
Organizing Successful New Service Development: A Literature Review
}

\begin{abstract}
Organizing new service development is an important topic for decision-makers in service firms, since continuous innovation is expected to pay off. Although the literature on organizing new service development has grown rapidly over the last decade, the numerous publications are highly fragmented, each concentrating on a small piece of the complex innovation puzzle. This paper classifies current literature on organizing new service development (NSD) into two evolutionary stages: managing key activities in the NSD process, and creating a climate for continuous innovation. For both stages its consequences for the initiation and implementation of new services are discussed. The paper ends with limitations and suggestions for future research.
\end{abstract}

\footnotetext{
About the authors

Jeroen de Jong works as a senior-researcher at EIM Small Business Research and Consultancy, Zoetermeer, the Netherlands.

Patrick Vermeulen is an assistant professor in strategic management at Erasmus University, Rotterdam, the Netherlands.
}

\section{Keywords}

Innovation, new service development, success factors, antecedents, organizational characteristics. 


\section{Organizing Successful New Service Development: A Literature Review ${ }^{1}$}

\section{Introduction}

Services constitute a major part of total economic activity and employment in most Western economies (OECD 2000; Anxo \& Storrie, 2001). A large share of innovative efforts in business is related to the development of new services (OECD, 2000; Howells, 2000). Despite its significance, many service firms still struggle with their innovative efforts. In financial services, for instance, new service development (NSD) is usually organized in a sequential manner (Vermeulen, 2001; Vermeulen \& Dankbaar, 2002). This approach results in long development lead times, communication problems, and increased costs. Similarly, Hart and Service (1993) discuss the lack of functional integration in a distribution company. Moreover, many service entrepreneurs refrain from explicitly organizing new service development. Rather than developing more formal structures to elicit ideas for new services, develop and select among them concurrently, service entrepreneurs regard it as an ad hoc process (see, for instance, Reidenbach \& Moak, 1986; Gallouj \& Weinstein, 1997; Martin \& Horne, 1993; Kelly \& Storey, 2000; Sundbo, 1997).

Yet, it seems to be worthwhile to explicitly organize the process of developing new services. Firms being most successful in providing new services prevent their innovation process from being ad hoc (De Brentani, 2001; Kelly \& Storey 2000). Many theorists have recognized this, resulting in a plethora of literature on how to organize new service development. Particularly in the past few years a rapid increase in the number of studies can be identified. Figure 1 below provides the reader with an idea of the number of studies on NSD over the last 15 years.

\footnotetext{
${ }^{1}$ We would like to thank Joris Meijaard, Anne Bruins and Wilfred Dolfsma for their contributions to previous versions of this article.
} 
--- Insert Figure 1 about here ---

Due to the plethora of publications, an integral overview of what has been studied seems to be lacking. The main goal of this paper is to provide an overview of the current literature on organizing new service development. Except for organizational characteristics, current literature also discusses product-based and environmental characteristics that can affect NSD (e.g. Johne \& Storey, 1998; De Jong et al., 2002). We do not elaborate on these; our focus is on organizational characteristics only.

The current body of research usually focuses on some particular sectors. Financial services are well covered (e.g. Storey \& Easingwood, 1996; Johne \& Harborne, 1985; Vermeulen), and the same applies to transport (e.g. Nijhof et al., 2002), telecommunications (e.g. Hellström \& Hellström, 2002) and wholesale (e.g. Hart \& Service, 1993). Most findings on organizing new service development are related to so-called production-intensive services. These services put considerable effort into the simplification of their service offerings, but are also keen on the adaptation of standardised services to particular user needs (Soete \& Miozzo, 1989; Evangelista \& Savona, 1998). Examples of production-intensive services include banks, insurances, telecommunications, transport and wholesale services. They should be distinguished from services where innovation is dominated by suppliers (such as personal services, hotels, restaurants and retail stores; these consumer-oriented services are often considered to be less innovative) or where innovation has a continuous, incremental nature due to high knowledge-intensity, such as in scientific, engineering and IT services (Soete \& Miozzo, 1989). Thus, the scope of our review is limited to production-intensive services. 
In this paper we will first define innovation and discuss what innovation in services implies. Subsequently, we will explain our search methods. Next, we will classify current literature on organizing NSD into two evolutionary stages: managing key activities in the NSD process, and creating a climate for continuous innovation. For both stages we have made an inventory of relevant organizational characteristics. We will discuss their effects on the initiation and implementation of new (production-intensive) services. Our paper ends with implications for managers, limitations and suggestions for future research.

\section{What is innovation in services?}

Nature of services. The differences between services and physical products have been well covered in the existing literature. Generally speaking, services tend to be intangible, heterogeneous, simultaneously produced and consumed, and perishable (e.g. Levitt, 1981; Zeithaml, 1981; De Brentani, 1991; Ennew et al., 1992; Johne \& Storey, 1998; Avlonitis et al., 2001). As a consequence, innovation in services mostly involves small and incremental changes in processes and procedures, and innovations in services are easier to imitate (Atuahene-Gima, 1996). It does not require much R\&D nor do service firms invest much in fixed assets to support innovations or spend much money on buying patents and licenses (Brouwer, 1997).

Dimensions of innovation in services. All definitions of innovation include the development and implementation of 'something new'. Apart from that, King and Anderson (2002) conclude that an innovation is aimed at producing some kind of benefit (profits, personal growth, etc.). It is restricted to intentional attempts to derive benefits from change. An idea is a necessary condition for an innovation, but cannot be called an innovation in itself. Fi- 
nally, innovation involves an application component, so just developing something new cannot be regarded as an innovation unless it is used.

Authors like Cook et al. (1999), Den Hertog (2000), Avlonitis et al. (2001), Gadrey et al. (1995) and Chase et al. (1998) have stressed that innovation in services can be related to changes in various dimensions. Some examples include innovation in the service concept, the client interface, the delivery system and technological options. Innovation in the service concept includes changes in the characteristics of the service itself. This dimension is most widely recognized.

Innovation in services can be related to a new client interface as well. Service offerings are increasingly marketed and produced in a client-specific way (even with client-specific pricing). Often, the characteristics and desires of existing and potential clients tempt a service firm to make adjustments in the client interface. This dimension of innovation can even entail clients acting as co-producers of the service offering (e.g., Van der Aa \& Elfring, 2002). One example of an innovation in the client interface is electronic data interchange (EDI).

Innovation in the delivery system refers to the internal organizational arrangements that have to be managed to allow service workers to perform their job properly, and to develop and offer innovative services (e.g., Cook et al., 1999; Gadrey et al., 1995; Den Hertog, 2000; Avlonitis et al., 2001). It could be interpreted as the internal work processes and arrangements. This type of change is often the direct result by the preceding ones (the linkage between the service provider and its client, and/or the service concept). Also, the capabilities, skills and attitudes of existing co-workers can make any necessary adjustments in the service delivery. One example of innovation that led to changes in the delivery system is the introduction of e-commerce, which required serious business process re-engineering efforts. E-commerce may have a substantial impact not only on the way in which the actual 
commercial transactions occur, but also on the processes preceding and following the transaction.

Although it was argued that service innovations are often non-technological, this is still the center of much analysis and debate (e.g. Kandampully, 2002). It is clear that service innovation is possible without technological innovation (Cooper \& De Brentani, 1991). Nonetheless, in practice, there is a wide range of relationships between technology and innovation in services. Examples of innovations with a strong technological component include tracking and tracing systems, enabling transport service providers to monitor the progress of their fleet and thus to manage their transport services more closely.

Following Den Hertog (2000), we stress that in real life it is difficult to provide 'pure' examples of the above-mentioned dimensions. Most new services will involve a combination of changes in various dimensions at once.

Results of innovation in services. The body of literature that focuses on the effects of having introduced new services is still low. Current research usually focuses on manufacturing (e.g., Loof et al., 2001; Arvantitis \& Hollenstein, 2002). This is partly due to the fact that services are poorly covered by innovation statistics (OECD, 2000). Besides, the intangible and simultaneous nature makes the impact of service innovations harder to trace than in manufacturing. Service innovations typically transform the state of customers (Tether \& Metcalfe, 2001).

Financial performance in services is believed to benefit from innovation (Kelly \& Storey 2000; De Brentani, 1989). Klomp and van Leeuwen (1999) provide some empirical evidence. Based on quantitative data gathered in Dutch firms, they conclude that innovation in general, and in service industries in particular, leads to better company performance in terms of revenue growth. In the case of more mature and established services, sales growth 
does not simply come from being able to offer low prices but also from a variety of nonprice factors, such as design and quality (Baden-Fuller \& Pitt, 1996). Apart from financial benefits, the literature reveals some other benefits for service firms, like creating customer value (e.g. Narver \& Slater, 1990) and increasing strategic success (Kay, 1993).

\section{Search Methods}

As was already mentioned in the introduction of this paper, we were mainly interested in literature covering issues related to organizing NSD. Studies were identified using three sources: (1) recent literature reviews on NSD, (2) a search of the ABI/Inform and Web of Science (Proquest) databases, and (3) a comprehensive review of relevant academic journals that we expected to have published papers on organizing NSD. Appropriate citations, such as books, conference proceedings and (EU/OECD) reports, in subsequent references were collected and included as well.

We started our search in the ABI/Inform and Web of Science (Proquest) databases by using the following three keywords: innovation, services, and new service development. We decided not to focus on organizational aspects from the beginning since this would have reduced the number of hits considerably. For instance, several articles are concerned with the role of an effective market launch or pre-testing (e.g. Davison et al., 1989). While these issues are clearly related to the organization of the NSD process, these would have been difficult to identify with a more focused search string. We first scanned the titles of articles to see whether they would fit our search. In case of doubt, abstracts and keywords in the articles were consulted. When this still did not clarify the suitability of the article under review, the full paper was printed and reviewed. After collecting all the articles we selected those that were managerially oriented. There are several service journals, e.g. Journal of Financial Services Research, that have a clear econometric focus. These were omitted from 
our sample. Since we were interested in organizational issues, we believed that these journals were of minor importance. The most important studies that we used are listed in Table 1. The last column refers to the evolutionary stage (see below) to which the paper contributes mostly.

--- Insert Table 1 about here ---

Next, we distributed all the material into five categories corresponding with publication date. We included studies covering the period 1988-2002. The reason for choosing this time period was that before 1988 there was no more than one journal article per year found. Older studies, such as Easingwood's classic 1986 paper, were also read and analyzed and can be found in the reference list. However, these are not included in the figures and tables in this paper.

Although there have been many valuable studies on (a) measuring the performance of new services and (b) identifying factors that are associated with success or failure, we decided not to include these in Table 1, as they gave us little information on what actually happens during the organization of NSD processes. This means that much of the valuable work of, for instance, de Brentani $(1989,1991)$ is not listed in this overview. These studies were identified, however, and included in Figure 1. Studies that studied success factors and elaborated on these factors were included (see for instance Edgett, 1994). What is most remarkable in table 1 is the almost exclusive emphasis on financial services. Nearly all the research projects focused on banks and insurance companies.

\section{Evolutionary stages in organizing new service development}


We have classified current insights on how to organize new service development into two evolutionary stages. The first stage concentrates on the management of key activities in the NSD process. However, in order to become more innovative, the effective organization of individual innovation projects is not sufficient. In the second evolutionary stage we identify some characteristics that create a climate for continuous innovation. Only when service firms manage to create an innovative climate they will be able to develop a continuous stream of innovations that increases their competitive advantage.

Both evolutionary stages relate to different parts of the innovation process. Of course, there have been many scholars who developed models describing the sequences of events in the innovation process. Most widely recognized is the two-stage model of Zaltman et al. (1973), dividing the innovation process into the stages of initiation and implementation. NSD authors have proposed similar models to describe how innovations are developed (see for instance Langeard et al., 1986; Scheuing \& Johnson, 1989a,b; Easingwood \& Percival, 1990; Edgett \& Jones, 1991; Edgett, 1994, 1996; Storey \& Easingwood, 1996; Kelly \& Storey, 2000). Figure 2 reveals our inventory of organizational characteristics in both evolutionary stages, along with their relationship to the stages of the innovation process. Below follows a detailed discussion.

--- Insert figure 2 about here ---

\subsection{Managing key activities}

In general, managing key activities enhances an effective implementation of new services. Current literature reveals eight organizational characteristics that directly enhance the development of innovative services. Some of them focus on the role of key persons in the 
innovation process (people), while the others aim to initiate formal structures that are most suitable for new service development.

People. It is widely believed that any organization's co-workers are at the heart of the innovation process (e.g. Schneider \& Bowen, 1984; Van de Ven, 1986). They are the ones who have to come up with ideas for new or improved services, and turn these into successful innovations.

The involvement of front-line employees increases the likelihood of a successful implementation of innovative services. Those who are responsible for sales and service delivery usually play an essential role in embodying a new service, in differentiating it from competitive services, and in helping clients to make the switching decision (Atuahene-Gima, 1996; Johne \& Storey, 1998). Consulting them before an implementation decision is made will enhance their motivation to strive for success. Co-workers who have considerable influence on decision-making tend to identify with an idea and perceive it to be 'their' innovation. Frontline-employees' knowledge of customers and competitive offerings can help in defining the appropriate level of service customization and user-friendliness (Martin \& Horne, 1995). Except for implementation, involving front-line employees can be beneficial for initiating new services as well. They usually have an excellent view on unsatisfied client needs and are the first to recognize opportunities for innovation (De Brentani, 2001).

The presence of a so-called product champion is another people-related element in organizing NSD. A product champion is someone in an informal role that pushes a new product or service beyond roadblocks within the organization (Shane, 1994). A champion occupies himself with persuading opponents and mobilizing resources. He plays a critical role in the implementation stage of an innovative development project. Research in manufacturing 
firms shows that successful firms are more likely to use and keep product champions. This is often not the case in service firms (Martin \& Horne, 1993; Vermeulen, 2001).

Management support is all about the daily behavior of those who are in charge. It is important that senior management consistently encourages innovation (Johne \& Vermaak, 1993; Johne, 1993; Martin \& Horne, 1995; Atuahene-Gima, 1996; Hellström \& Hellström, 2002). In the initiation stage, managers should encourage creative behavior and the development of ideas, not only by emphasizing the importance of innovation in words, but also by setting examples with their own actions (Debackere et al., 1998). In the latter stages of the NSD process management support is also needed. The outcome of an innovation project is always uncertain, and co-workers must be convinced that they will not be punished for failure.

Structure. To enhance efficiency and effectiveness, organizations can initiate formal systems of work relationships to divide up various work tasks between co-workers, and to provide co-ordination between these tasks. Of course, managers can initiate structure to new service development activities as well.

Much of the NSD literature discusses some formal systems and tools that can (a) trigger and channel employee creativity, such as creativity techniques and formal systems to gather and screen promising ideas of co-workers and (b) provide rules and procedures to guide the development process (Bowers, 1989; Scheuing \& Johnson, 1989a, 1989b; Avlonitis et al., 2001; Meyer \& DeTore, 2001). Such tools can be beneficial to initiate new service development (Kelly \& Storey, 2000). Of course, creativity techniques like brainstorming serve as a direct trigger to generate ideas for innovations. Research evidence in service firms suggests a positive relationship with co-workers' innovative behavior (De Jong \& Kemp, 2001). Van Dijk and van den Ende (2002) investigated the effects of formal systems 
to gather ideas of co-workers and to judge and select among them. Their analysis includes a case study in a service firm (telecom provider) as well. Although the effects on innovative success depend on other organizational conditions (like an innovative culture), they conclude that using formal systems can certainly be beneficial. However, formal systems to manage the innovation process have been found to be a rare species in service firms (Chan et al., 1998).

The employment of multifunctional teams contributes directly to the overall effectiveness of developing new services (Avlonitis et al., 2001). Gallouj and Weinstein (1997) reflect this belief in their statement that flexible, cross-functional teams are successful in development activities because of the new combinations of knowledge and competencies they offer to service organizations. This also increases problem-solving ability when obstacles arise in the implementation stage. It is very important that representatives from functional departments co-operate and share information during the development process (Hart \& Service, 1993; Edgett \& Parkinson, 1994). Firms that develop new services without using multifunctional teams may suffer from functionally departmentalized structures that impede NSD (Vermeulen, 2001; Vermeulen \& Dankbaar, 2002).

The availability of resources is particularly important in the implementation stage. Time and money are required to develop new services. Money can be a problem in a service environment, because the attitude of financial institutions towards financing innovation is still determined by typical manufacturing innovations. Investment in innovative service concepts is not an asset banks are very pleased to lend money against, because there is no inherent material security (Preisl, 1998). Also, employees should be explicitly assigned to development projects. When employees are allowed to work on NSD only a small part of their time, they experience working on a project as something additional to their daily activities, which often results in longer development times because team members' priorities 
are with their daily work. Projects that are carried out by teams with at least a few full-time team members are finished much quicker (Vermeulen, 2001).

Generally, service firms refrain from organizing a pre-launch test before market launch (Davison et al., 1989). Research evidence shows that successful service firms evaluate new services in a formal market test and use customer feedback to further refine an innovative service (De Brentani, 2001; Easingwood \& Percival, 1990). The lack of testing is partly due to the fact that a large number of new services are copied from competitors. Service firms see no need for testing because the risk of a 'me-too' service is perceived to be low. Another argument is that formal quantitative research is generally not a reliable way to assess consumer acceptance of a new service. Instead, qualitative techniques such as mystery shopping should be used, but these seem to provide only soft information on acceptance rates (Langeard et al., 1986).

Conducting market research is important to understand customer needs and preferences and allows firms to design new products to fit different profiles of customers (Storey \& Easingwood, 1993; Edgett \& Parkinson, 1994). The proficiency of market launch is another activity that can be formally structured as part of an NSD project (Atuahene-Gima, 1996; Avlonitis \& Papastathopoulou, 2001; De Brentani, 2001) and often depends on its timeliness (Chryssochoidis \& Wong, 2000). A careful market launch consists of training of front-line co-workers, effective marketing and evaluation of the results of the launch. Synergy with existing marketing efforts is important as well. A new service should fit the firm's marketing competencies such as the skills of sales representatives, promotion and distribution systems, and customer service (Edgett, 1994; Storey and Easingwood, 1996).

\subsection{Creating a climate for continuous innovation}


When managers have put considerable effort in better organizing key NSD activities, the next step includes creating a climate supporting continuous innovation. Again, managers' interventions can be aimed at people and structural characteristics. Below we elaborate on both subjects.

People. As discussed above, it is people who should generate ideas and strive for successful implementation (e.g. Van de Ven, 1986). The people-related characteristics we discuss hereafter positively affect both stages of the NSD process, as they enhance co-workers' creativity and commitment to innovation.

First, service managers can stimulate their co-workers to have frequent external contacts. Examples of external contacts include contacts with customers (Gustafsson et al., 1999; Martin et al., 1999; Kandampully, 2002) and suppliers, being informed on competitors' actions, and attending conferences and fairs. The literature indicates that having frequent external contacts paves the way for opportunity exploration and the generation of ideas. (e.g. Martin \& Horne, 1995; Sundbo, 1997, 1998; De Brentani, 2001; Alam \& Perry, 2002). External contacts provide a service firm with the opportunity to collect feedback on their current service offerings (Davison et al., 1989; Thwaites \& Edgett, 1991). When a service firm is sensitive to signals from its clients, innovation success is more likely (Bortree, 1991). Another external contact includes being informed on competitors. Due to the ease of copying, they have been identified as an important source of ideas for 'new' services (e.g. Easingwood, 1986; Hooley \& Mann, 1988). For instance, Teixeira and Ziskin (1993) found that approximately 80 per cent of banks and insurance companies view their competitors as the main source of innovations.

Second, managers could stimulate information sharing among co-workers. An important dimension of an innovation-enhancing firm climate is whether information is shared or 
protected and communication between departments is encouraged (Lievens et al., 1999; Lievens \& Moenaert, 2000a; McCabe, 2000). Open cultures provide better support for the exchange of ideas (Lievens \& Moenaert, 2000b). A large diversity of information affects the idea-generating ability of the workforce. It also improves the problem-solving capacity of the firm, preventing mistakes from being made in future NSD projects (Van der Aa, 2000). On the other hand, problems of communication between various functional specialists can slow down and decrease the success of innovative activities (Vermeulen \& Dankbaar, 2002). Thus, both tasks in the NSD process can benefit from sharing information.

Another people-related characteristic is providing employees with sufficient autonomy. Autonomy is the extent to which followers are given latitude to carry out their tasks without excessive supervision (Basu \& Green, 1997). A positive association with innovation results has been found in several empirical studies, such as those by Nijhof et al. (2002) in a transport firm. When co-workers experience autonomy, they feel less constrained to explore opportunities and to generate ideas. Initiating new services can benefit from this.

Structure. Except for people-related characteristics, managers may better organize some structural factors that positively affect new service development on a more continuous basis. These include strategic focus and vision, training and education, internal organization (including task rotation) and investments in information technology. Again, both stages of the NSD process may benefit from this.

Strategic focus would probably make a difference for many service firms. Many authors have stressed that clear goals should be set for the NSD program as a whole (Edgett, 1993; Edvardsson et al., 1995; Johne \& Storey, 1998; Johne \& Davies, 2000). Strategic focus on innovation appears to be an important determinant of employees' creative contributions and efforts to make new services successful (De Jong \& Kemp, 2001). New service efforts 
should fit with the overall strategy of the firm. It ensures that a new service is developed for a clearly identified target market that is important for the company's future, and it better guarantees that there is a fit with the resources of the developing firm (people, knowledge, investment funds) (De Brentani, 2001). A clear vision from top management to where the organizations is heading is crucial for innovation efforts to be successful (Thwaites \& Edgett, 1991; Thwaites, 1992; Johne \& Davies, 2000).

Training and education improve the knowledge and skills of current staff in general and those who are responsible for implementing innovations in particular. Not having a qualified development staff is a major barrier in many NSD projects (Drew, 1995a; Johne \& Harborne, 1985). Service firms usually need detailed knowledge about trends and developments in a firm's basic technologies, customers and delivery processes. Such knowledge is critical for an effective implementation of new services and determines the success of innovative service concepts, new client interfaces and delivery systems.

The internal organization is also of the highest importance in creating a more innovative organization (Thwaites \& Edgett, 1991; Iwamura \& Jog, 1991; Thwaites, 1992; Johne, 1993; Drew, 1995b; Edvardsson et al., 1995; Vermeulen, 2001). Some organizations have specialized innovation departments, meaning that they created a special place for new products to be developed (Sundbo, 1997). Besides creating a special place for innovation, other ways of increasing the innovative potential of organizations include certain types of organizational structures (Scarbrough \& Lannon, 1989; Johne, 1993; Vermeulen, 2001) and task rotation (De Jong \& Kemp, 2001). Task rotation, meaning the frequent exchanging of tasks and jobs among employees, is a method to broaden the employee's point of view. Task rotation supports both stages of the NSD process (De Jong \& Kemp, 2001). Work experience in different job areas enhances creative potential, since the broad experience gained by employees will enable them more often to come up with ideas for im- 
provement in services, delivery processes, etc. Besides, a work broad experience increases their problem-solving ability when new services are developed.

In section 2 we already discussed that technological options can be a dimension of an innovative service itself. Here, we stress that information technology (IT) also provides a range of possibilities to support the NSD process. It is relevant for the initiation of new services, because IT can be a tool for better information sharing. An example includes using the Internet to systematically gather information on competitors' services. IT also has the ability to accelerate the implementation of new services (Huete \& Roth, 1988). One could think of a central database with product information to ensure that every sales worker offers the most recent version of a new service. On the other hand, when IT imposes adjustments in service concepts that do not fit clients, it constrains the successful implementation of new services (Vermeulen, 2001; Vermeulen \& Dankbaar, 2002).

\section{Discussion}

Today, the services sector offers a tremendous potential for growth and profitability. Their leaders face the challenge to realise a flow of innovations to ensure better results and longterm survival. The two stages that we identified in the literature have contributed to a better understanding of how service firms can manage their NSD projects more effectively and how they may be able to create a climate for innovation. Much has been accomplished in the last 15 years regarding to the key activities. Most service firms are well aware of the need for involving employees, keeping top management support during the process and use multifunctional teams for developing their new services. They still seem to be lacking on activities such as testing and market launch and real product champions are a rare species in service firms (Vermeulen, 2001). Although the number of studies focusing on creating an innovative climate has increased, many service firms still lack the capabilities to inno- 
vate continuously (see also Benders \& Vermeulen, 2002). There is still some work to be done in this line of research.

Implications for managers. A first important lesson of this paper is that managers who believe that innovation is always related to technology find themselves deceived. Innovation in services can be aimed at other dimensions like a new service concept, client interface or delivery system, and technology is not necessarily part of it. Since technology is not always a dimension, it becomes clear that innovation in services is widespread and frequently present.

Although many service managers regard new service development as something that just 'happens', we found that many things can be done to enhance innovation success. Drawing on earlier work, this paper reviewed organizational characteristics that influence new service development. Understanding these characteristics allows service managers to become aware of issues that need to be taken into consideration when trying to improve NSD. The findings from this paper may be used as a diagnostic tool.

We made a distinction between two evolutionary stages in better organizing new service development. First, managers can focus on some key activities in the NSD process directly. These are related to the role of key persons (involving frontline employees in the NSD process, recruiting product champions and providing management support) and to structural arrangements optimized for new service development (by using funnel tools and multifunctional teams, providing sufficient resources and paying attention to testing and market launch). When looking at the stages of the NSD process, such activities seem particularly useful for an effective implementation of new services. Second, managers should be aware of some characteristics that have an impact on NSD as they create an innovative climate for the firm. Again, these are related to people and structure. People-related charac- 
teristics include co-workers having frequent external contacts and sharing information, and securing co-workers' autonomy. Structure-based characteristics are related to strategic focus, training and education, task rotation and information technology. Looking at the stages of the NSD process, such characteristics tend to strengthen a climate that supports idea generation and the initiation of new services.

All in all, current literature suggests that NSD is a controllable event and should not be regarded as 'something ad-hoc'. However, the process itself should be rather flexible when it is implemented in a service firm. Service managers must be aware of the dark side of formalization: excessive rules and procedures may have the opposite effect. An overkill of formalization is devastating for creativity and innovation (Edvardsson et al., 1995; Bodewes, 2000). Thus, service managers face the challenge to find a sound balance between organization and freedom.

Limitations and suggestions for research. This paper revealed several limitations that need to be addressed. On the basis of our review we distinguished two evolutionary stages in better organizing new service development: 1. manage key innovation activities and 2. create a climate to support continuous innovation. Empirical evidence for the characteristics in the second stage is still scare, so the main focus for researchers in service firms should be aimed at this stage.

Second, as discussed in section 1 and shown in table 1, much of the current literature is limited to production-intensive services like banks, insurances, transport, wholesale and telecommunications. It implies that our findings cannot be generalized to other service sectors like knowledge-intensive firms (engineering, IT services, etc.) or supplier-dominated services (such as personal services, hotels and restaurants). Future research should explore 
relevant organizational characteristics for these sectors, and establish its differences with production-intensive services.

Another limitation is related to the widely used stage-based model to describe the process of new service development. It is remarkable that almost no empirical evidence can be found for service innovations passing through discrete stages. Instead, the innovation process seems to be non-linear with many factors influencing innovative outcomes (Kline \& Rosenberg, 1986). Future research should focus more often on alternative descriptions of the NSD process.

Fourth, we concluded that relatively few studies have focused on the effects of having introduced new services. We started our paper with the argument that many service entrepreneurs regard NSD as an ad-hoc process, and more knowledge on positive outcomes of explicit innovative efforts would certainly boost their willingness to better organize the innovation process.

Service firms are the heart of many modern societies. Yet, many service firms are not very innovative. The European Union has prioritized service research in order to be more aware of how these firms can be stimulated to further improve their innovative performances (OECD, 2000). Individual countries have also been alarmed by the sorry state of innovation in service firms. In the Netherlands, for instance, newspapers have reported about the drop in innovation output because of the increased emphasis on services in the economy. The Dutch government has called out to academics to focus their research projects on service innovation. In order for countries to achieve a higher level of innovation, service firms need to do their share of the work. This challenge is still waiting to be accepted by service firms and researchers. 


\section{References}

Aa, W. van der (2000), Organisatorische Innovaties en Groeistrategieën van Dienstverlenende Bedrijven, Dissertation Erasmus University Rotterdam.

Aa, W. van der \& T. Elfring (2002), 'Realizing innovation in services', Scandinavian Journal of Management, Vol. 18, pp. 155-171.

Alam, I. \& C. Perry (2002), 'A customer-oriented new service development process', Journal of Services Marketing, Vol. 16 No. 6, pp. 515-534.

Anxo, D. \& D. Storrie (2001), The job creation potential of the service sector in Europe, Luxembourg: EC. Arvantitis S. \& H. Hollenstein (1994) 'Industrial Innovation in Switzerland: a model-based analysis with survey data' in: Kleinknecht A. (1996), Determinants of innovation, the message from new indicators, London: Macmillan Press ltd, pp. 13-63.

Atuahene-Gima, K. (1996), 'Differential potency of factors affecting innovation performance in manufacturing and services firms in Australia', Journal of Product Innovation Management, Vol. 13, pp. 35-52.

Avlonitis G. J., P.G. Papastathopoulou (2000), 'Marketing Communication and product performance: innovative vs non-innovative new retail financial products', International Journal of Bank Marketing, Vol. 18 No. 1, pp. 27-41.

Avlonitis G.J., P.G. Papastathopoulou \& S.P. Gounaris (2001), 'An empirically-based typology of product innovativeness for new financial services: Success and failure scenarios', The Journal of Product Innovation Management, Vol. 18 No. 5, pp. 324-342.

Baden-Fuller, C. \& M. Pitt (1996), Strategic innovation, Routledge: London.

Basu, R. \& S.G. Green (1997), 'Leader-member exchange and transformational leadership: An empirical examination of innovative behaviors in leader-member dyads', Journal of Applied Social Psychology, Vol. 27 No. 6, pp. 477-499

Bodewes, W.E.J. (2000). Neither Chaos Nor Rigidity: An empirical study on the effect partial formalization on organizational innovativeness, Dutch University Press, Tilburg.

Bortree, W.H. (1991), 'Consumer input: the key to new product success', Bankers Magazine, May/April, pp. 14-20.

Bowers, M.R. (1989), 'Developing new services: improving the process makes it better', Journal of Services Marketing, Vol. 3 No. 1, pp. 15-20.

Brouwer E., (1997), Into innovation: determinants and indicators, Phd. University of Amsterdam, Utrecht: Drukkerij Elinkwijk b.v.

Chan, A., F.M. Go \& R. Pine (1998), 'Service Innovation in Hong Kong: Attitudes and Practice', The Service Industries Journal, Vol. 18 No. 2, pp. 112-124.

Chase, R.B., N.J. Aquilano, \& F. Jacobs (1998), Operations Management for Competitive Advantage, Boston: McGraw Hill.

Chryssochoidis, G.M. \& V. Wong (2000), 'Service Innovation multi-country launch: causes of delays', European Journal of Innovation Management, Vol. 3 No. 1, pp. 35-44.

Cook, D.P., C.H. Goh, C.H. Chung (1999), 'Service typologies: a state of the art survey', Production and Operations Management, Vol. 8 No. 3, pp. 318-338.

Cooper, R.G. \& U. de Brentani (1991), 'New industrial financial services: what distinguishes the winners', Journal of Product Innovation Management, Vol. 8 No. 2, pp. 75-90.

Cooper, R.G. \& S.J. Edgett (1999), Product development for the service sector. Lessons from market leaders. Cambridge, MA: Perseus Books.

Davison, H., T. Watkins \& M. Wright (1989), 'Developing new personal financial products - some evidence on the role of market research', International Journal of Bank Marketing, Vol. 7 No. 1, pp. 8-15.

De Brentani, U. (1989), 'Success and failure in new industrial services', Journal of Product Innovation Management Vol. 6, pp. 239-258.

De Brentani, U. (1991), 'Success factors in new developing new business services', European Journal of Marketing, Vol. 25 No. 2, pp. 33-59.

De Brentani, U. (1993), 'The new product process in financial services: Strategy for success', International Journal of Bank Marketing, Vol. 11 No. 3, pp. 15-22.

De Brentani, U. (2001), 'Innovative versus incremental new business services: different keys for achieving success', Journal of Product Innovation Management, Vol. 18 No. 3, pp. 169-187.

De Jong, J.P.J. \& R. Kemp (2001), 'Innovatief gedrag van medewerkers in dienstverlenende bedrijven', M\&O: tijdschrift voor management \& organisatie, Vol. 55 No. 5, pp. 5-20.

De Jong, J.P.J., W. Dolfsma, A. Bruins \& J. Meijaard (2002), Innovation in service firms explored: what, how and why, EIM: Zoetermeer. 
Debackere, K., B. van Looy \& P. Papastathopoulou (1998), Managing innovation in a service environment, in: Looy van, B., Dierdonck van, R. \& Gemmel, P. (1998), Services Management: An Integrated Approach. London: Financial Times/Pitman Publishing, 387-405.

Den Hertog, P. (2000), 'Knowledge-intensive business services as co-producers of innovation', International Journal of Innovation Management, Vol. 4 No. 4, pp. 491-528.

Dijk, Ch. van, \& J. van den Ende (2002), 'Suggestion systems. Transferring employee creativity into practicable ideas', R\&D Management, Vol. 32 No. 5, pp. 387-395.

Drew, S. (1995a), 'Accelerating innovation in financial services', Long Range Planning, Vol. 28, No. 4, pp. 11-21.

Drew, S. (1995b), 'Strategic benchmarking: innovation practices in financial institutions', International Journal of Bank Marketing, Vol. 13 No. 1, pp. 4-16.

Easingwood, C.J. (1986) 'New product development for service companies', Journal of Product Innovation Management, Vol. 3 No. 4, pp. 264-275.

Easingwood, C.J. \& J. Percival (1990), 'Evaluation of new financial services', International Journal of Bank Marketing, Vol. 8 No. 6, pp. 3-8.

Edgett, S. \& S. Jones (1991), New Product Development in the Financial Service Industry: a Case Study, Journal of Marketing Management, Vol. 7, pp. 271-284.

Edgett, S. (1993), 'Developing new financial services within UK building societies', International Journal of Bank Marketing, Vol. 11 No. 3, pp. 35-43.

Edgett, S. (1994), 'The traits of successful new service development', Journal of Services Marketing, Vol. 8 No. 3, pp. 40-49.

Edgett, S. (1996), 'The new product development process for commercial financial services', Industrial Marketing Management, Vol. 25 No. 6, pp. 507-515.

Edgett, S. \& S. Parkinson (1994), 'The Development of New Financial Services. Identifying Determinants of Success and Failure', International Journal of Service Industry Management, Vol. 5 No. 4, pp. 24-38.

Edvardsson, B., Haglund, L. \& Mattsson, J. (1995), 'Analysis, planning, improvisation and control in the development of new services', International Journal of Service Industry Management, Vol. 6 No. 2, pp. 2435 .

Edvardsson, B., Gustafsson, A., M.D. Johnson \& Sandén, B. (2000), New Service Development and Innovation in the New Economy. Lund: Studentliteratur.

Ennew, C., P. Wong \& M. Wright (1992), 'Organisational structures and the boundaries of the firm: acquisition and divestment in financial services', The Service Industries Journal, vol. 12 no. 4, pp. 478-497.

Evangelista, R. \& M. Savona (1998), Patterns of Innovation in Services: The results of the Italian Innovation Survey, Paper presented to the 7th Annual RESER Conference, Berlin, 8-10 October.

Fernandez, A.M. (2001), 'Innovation processes in an accident and emergency department', European Journal of Innovation Management, Vol. 4 No. 4, pp. 168-178.

Gadrey, J., F. Gallouj \& O. Weinstein (1995), 'New Modes of Innovation: How services benefit industry', International Journal of Service Industry Management, Vol. 6 No 3, pp. 4-16.

Gallouj, F. \& O. Weinstein (1997), Innovation in services, Research Policy 26, p. 537-556.

Gustafsson, A., F. Ekdahl \& B. Edvardsson (1999), 'Customer Focused Service Development in Practice. A case stuy at Scandinavian Airlines System (SAS)', International Journal of Service Industry Management, Vol. 10 No 4, pp. 344-358.

Hart, S.J \& L.M. Service (1993), Cross-functional Integration in the New Product Introduction Process: An Application of Action Science in Services, International Journal of Service Industry Management, Vol. 4, No. 3, pp. 50-66.

Hellström, C. \& T. Hellström (2002), Highways, alleys and by-lanes: charting the pathways for ideas and innovation in organizations, Creativity and Innovation management, Vol. 11 No. 2, pp. 107-114.

Hooley, G. \& Mann, S. (1988), 'The adoption of marketing by financial institutions', The Service Industry Journal, Vol. 5 No. 3, pp. 261-72.

Howells, J. (2000) Innovation \& Services: new conceptual frameworks. University of Manchester, CRIC discussion paper no 38, August.

Huete, L. \& A.V. Roth (1988), The industrialization and Span of Retail Banks' delivery systems, International Journal of Operations and Production Management, Vol. 8, pp. 46-66.

Iwamura, A. \& V.M. Jog (1991), 'Innovators, Organization Structure and Management of the Innovation Process in the Securities Industry', Journal of Product Innovation Management, Vol. 8, pp. 104-116.

Johne, A. \& P. Harborne (1985), 'How large commercial banks manage product innovation', International Journal of Bank Marketing, Vol. 3 No. 1, pp. 54-70. 
Johne, A. (1993), 'Insurance Product Development: Managing the Changes', International Journal of Bank Marketing, Vol. 11 No. 3, pp. 5-14.

Johne, A. \& L. Vermaak (1993), 'Head office involvement in financial product development', International Journal of Bank Marketing, Vol. 1 No. 3, pp. 28-34.

Johne, A. \& P. Pavlidis (1996), 'How banks apply marketing expertise to develop new derivatives', Journal of Product Innovation Management, Vol. 13, No. 5, pp. 440-452.

Johne, A \& C. Storey (1998), 'New Service Development: A Review of the Literature and Annotated Bibliography', European Journal of Marketing, Vol. 32 No. 3/4, pp. 184-252.

Johne, A. \& R. Davies (2000), 'Innovation in medium-sized insurance companies: how marketing adds value', International Journal of Bank Marketing, Vol. 18 No. 1, pp. 6-14.

Kandampully, J. (2002) 'Innovation as the core competency of a service organization: the role of technology, knowledge and networks' European Journal of Innovation Management, Vol. 5 No. 1, pp. 18-26.

Kay, J. (1993), Foundations of corporate success: how business strategies add value, Oxford University Press, Oxford.

Kelly, D. \& C. Storey (2000), 'New service development: initiation strategies', International Journal of Service Industry Management, Vol. 11 No. 1, pp. 45-62.

King, N. \& N. Anderson (2002), Managing innovation and change: a critical guide for organizations, London: Thomson

Klomp, L. en G. van Leeuwen (1999), The importance of innovation for firm performance, Statistics Netherlands: Voorburg.

Langeard, E., P. Reffait \& P. Eiglier (1986), 'Developing new services', in Venkatesan, M., Schmalensee, D.M. \& Marshall, C. (Eds), Creativity in Services Marketing, American Marketing Association, Chicago, IL, pp. $120-23$.

Levitt, T. (1981), 'Marketing intangible products and product intangibles', Harvard Business Review, Vol. 59 No. 3, pp. 94-102.

Lievens, A., R.K. Moenaert \& R. S'Jegers (1999), 'Linking communication to innovation success in the financial serivces industry: a case study analysis', International Journal of Service Industry Management, Vol. 10 No. 1, pp. 23-47.

Lievens, A. \& R.K. Moenaert (2000a), 'Project Team Communication in Financial Service Innovation', Journal of Management Studies, Vol. 37 No. 5, pp. 733-766.

Lievens, A. \& R.K. Moenaert (2000b), 'Communication flows during financial service innovation', European Journal of Marketing, Vol. 34 No. 9/10, pp. 1078-1110.

Loof, H., A. Heshmati, R. Asplund \& S.O. Naas (2001), Innovation and performance in manufacturing industries: a comparison of the Nordic countries, SSE/EFI working paper series in economics and finance no. 457, pp. 38.

Martin, C.R. \& D.A. Horne (1993), 'Services innovation: successful versus unsuccessful firms', International Journal of Service Industry Management, Vol. 4, pp. 48-64.

Martin, C.R. \& D.A. Horne (1995), 'Level of success inputs for service innovations in the same firm', International Journal of Service Industry Management, Vol. 6 No. 4, pp. 40-56.

Martin, C.R., D.A. Horne \& A.M. Schultz (1999), 'The business-to-business customer in the service innovation process', European Journal of Innovation Management, Vol. 2 No. 2, pp. 55-62.

McCabe, D. (2000), 'The Swings and Roundabouts of Innovating for Quality in UK Financial Services', The Service Industries Journal, Vol. 20 No. 4, pp. 1-20.

Meyer, M.H. \& A. DeTore (2001), 'Perspective: Creating a platform-based approach for developing new services', Journal of Product Innovation Management, Vol. 18, pp. 188-204.

Narver, J.C. \& F.S. Slater (1990), 'The effect of a market orientation on business profability', Journal of Marketing, October, 20-35.

Nijhof, A., K. Krabbendam \& J.K. Looise (2002), Innovation through exemptions: building upon the existing creativity of employees, Technovation, Vol. 22 No. 11, pp. 675-683.

OECD (2000), Promoting innovation and growth in services, Organisation for Economic Co-operation and Development: Paris.

Preisl, B. (1998), Barriers to innovation in services, SI4S nr. 2. STEP Group Oslo.

Reidenbach, R.E. \& D.L. Moak (1986), 'Exploring Retail Bank Performance and New Product Development: A Profile of Industry Practices', Journal of Product Innovation Management, Vol. 3 No. 3, pp. 187194.

Scarbrough, H. \& R. Lannon (1989), 'The Management of Innovation in the Financial Services Sector: a Case study', Journal of Marketing Management, Vol. 5 No 1, pp. 51-62. 
Scheuing, E.E. \& E.M. Johnson (1989a), 'A proposed model for new service development', Journal of Services Marketing, Vol. 3, No. 2, pp. 25-34.

Scheuing, E.E. \& E.M. Johnson (1989b), 'New product development and management in financial institutions', International Journal of Bank Marketing, Vol. 7 No. 2, pp. 17-21.

Schneider, B. \& D.E. Bowen. (1984), 'New service design, development and implementation and the employee', in George, W.R. \& Marshall, C.E. (Eds), Developing New Services, American Marketing Association, Chicago, IL, pp. 82-101.

Shane, S.A. (1994), 'Are champions different from non-champions?', Journal of Business Venturing, Vol. 9 No. 5, pp. 397-421.

Soete, L. \& M. Miozzo (1989), Trade and development in services: a technological perspective. Working paper No. 89-031, Merit Maastricht

Storey, C. \& C.J. Easingwood (1993), 'The Impact of the New Product Development Project on the Success of Financial Services', The Service Industries Journal, Vol. 13 No. 3, pp. 40-54.

Storey, C. \& C.J. Easingwood (1996), 'Determinants of new product performance: a study in the financial services sector', International Journal of Service Industry Management, Vol. 7, No. 1, pp. 32-55.

Sundbo, J. (1997), 'Management of Innovation in Services', The Service Industries Journal, Vol. 17 No. 3, $432-455$.

Sundbo, J. (1998), The Organization of Innovation in Services, Roskilde University Press, Roskilde.

Teixeira, D. \& J. Ziskin (1993), 'Achieving quality with customer in mind', Bankers Magazine, January/February, pp. 29-35.

Terrill, C.A. (1992) 'The ten commandments of new service development' Management Review, February, pp. 24-27.

Tether, B.S. \& J.S. Metcalfe (2001), Services and Systems of Innovation, paper at DRUID 2002.

Thwaites, D. \& S. Edgett (1991), 'Aspects of Innovation in a Turbulent Market Environment: Empirical Evidence from UK Building Societies', The Service Industries Journal, Vol. 11 No. 3, pp. 346-361.

Thwaites, D. (1992), 'Organisational influences on the new product development process in financial services', Journal of Product Innovation Management, Vol. 9, No. 4, pp. 303-313.

Van de Ven, A. (1986). Central problems in the management of innovation. Management Science, Vol. 32, pp. 590-607

Van der Aa, W. \& T. Elfring (2002), 'Realizing innovation in services', Scandinavian Journal of Management, Vol. 18 No. 2, pp. 155-171.

Van der Aa, W. (2000), Organisatorische innovaties en groeistrategieën van dienstverlenende bedrijven, EUR: Rotterdam.

Vermeulen, P.A.M. \& B. Dankbaar (2002), The organisation of product innovation in the financial sector, The Service Industries Journal, Vol. 22 No. 3, pp. 77-98.

Vermeulen, P.A.M. (2001) Organizing Product Innovation in Financial Services. Nijmegen University Press. Zaltman, G., R. Duncan \& J. Holbek (1973). Innovations and Organizations, New York: Wiley.

Zeithaml, V.A. (1981) 'How consumer evaluation processes differ between goods and services' in: J.H. Donnelly \& W.R. George (eds.) Marketing of Services. Chicago: American Marketing Association. 
NSD publications in the last 15 years

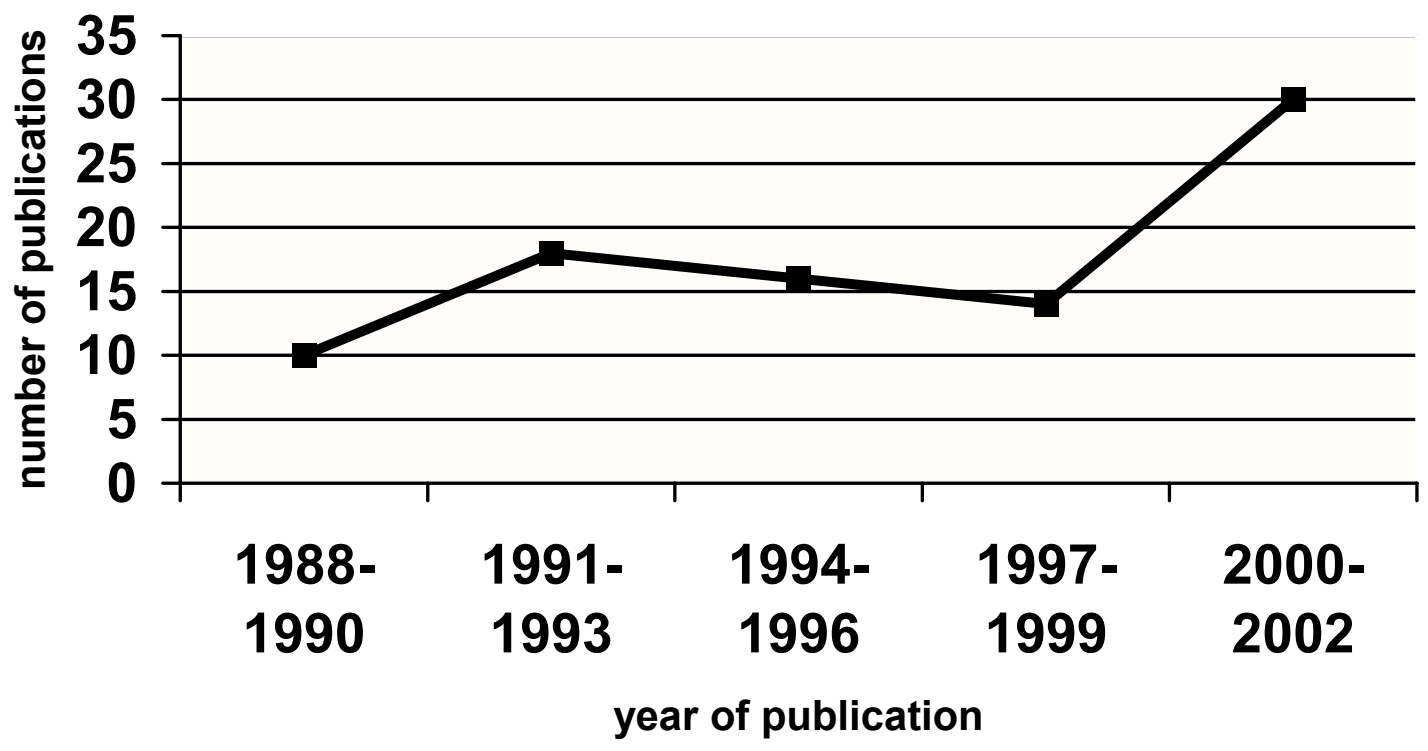

Figure 1 NSD publications in the last 15 years 


\begin{tabular}{|c|c|c|c|c|}
\hline $\begin{array}{l}\text { Journals with } \\
\text { most published } \\
\text { articles on NSD } \\
\end{array}$ & $\begin{array}{l}\text { Authors with specific } \\
\text { focus on organizing NSD }\end{array}$ & $\begin{array}{l}\text { Year of } \\
\text { Study }\end{array}$ & $\begin{array}{l}\text { Type of services } \\
\text { studied }\end{array}$ & $\begin{array}{l}\text { Evolutionary stage to } \\
\text { which study contributes } \\
\text { mostly }\end{array}$ \\
\hline $\begin{array}{l}\text { International Jour- } \\
\text { nal of Bank Market- } \\
\text { ing }\end{array}$ & $\begin{array}{l}\text { Avlonitis \& Papastathopolou } \\
\text { Johne \& Davies } \\
\text { Drew } \\
\text { Johne } \\
\text { Johne \& Vermaak } \\
\text { De Brentani } \\
\text { Edgett } \\
\text { Easingwood \& Percival } \\
\text { Scheuing \& Johnson } \\
\text { Davison et al. }\end{array}$ & $\begin{array}{l}2000 \\
2000 \\
1995 \\
1993 \\
1993 \\
1993 \\
1993 \\
1990 \\
1989 \\
1989 \\
\end{array}$ & $\begin{array}{l}\text { Financial Services } \\
\text { Financial Services } \\
\text { Financial Services } \\
\text { Financial Services } \\
\text { Financial Services } \\
\text { Financial Services } \\
\text { Financial Services } \\
\text { Financial Services } \\
\text { Financial Services } \\
\text { Financial Services }\end{array}$ & $\begin{array}{l}\text { Managing key activities } \\
\text { Creating innovative climate } \\
\text { Creating innovative climate } \\
\text { Creating innovative climate } \\
\text { Managing key activities } \\
\text { Managing key activities } \\
\text { Creating innovative climate } \\
\text { Managing key activities } \\
\text { Managing key activities } \\
\text { Managing key activities }\end{array}$ \\
\hline $\begin{array}{l}\text { Journal of Product } \\
\text { Innovation Man- } \\
\text { agement }\end{array}$ & $\begin{array}{l}\text { Avlonitis et al. } \\
\text { De Brentani } \\
\text { Meyer \& de Tore } \\
\text { Atuahene-Gima }\end{array}$ & $\begin{array}{l}2001 \\
2001 \\
2001 \\
1996\end{array}$ & $\begin{array}{l}\text { Financial Services } \\
\text { Business Services } \\
\text { Financial Services } \\
\text { Financial Services, } \\
\text { Computer software, } \\
\text { ICT, Others (incl. Con- } \\
\text { sulting, engineering) }\end{array}$ & $\begin{array}{l}\text { Managing key activities } \\
\text { Managing key activities } \\
\text { Managing key activities } \\
\text { Managing key activities }\end{array}$ \\
\hline & $\begin{array}{l}\text { Johne \& Pavlidis } \\
\text { Thwaites } \\
\text { Iwamura \& Jog }\end{array}$ & $\begin{array}{l}1996 \\
1992 \\
1991\end{array}$ & $\begin{array}{l}\text { Financial Services } \\
\text { Financial Services } \\
\text { Financial Services }\end{array}$ & $\begin{array}{l}\text { Creating innovative climate } \\
\text { Creating innovative climate } \\
\text { Creating innovative climate }\end{array}$ \\
\hline $\begin{array}{l}\text { International Jour- } \\
\text { nal of Service Indus- } \\
\text { try Management }\end{array}$ & $\begin{array}{l}\text { Lievens et al. } \\
\text { Gustafsson et al. } \\
\text { Storey \& Easingwood } \\
\text { Martin \& Horne } \\
\text { Edvardsson et al. } \\
\text { Edgett \& Parkinson } \\
\text { Martin \& Horne } \\
\text { Hart \& Service } \\
\end{array}$ & $\begin{array}{l}1999 \\
1999 \\
1996 \\
1995 \\
1995 \\
1994 \\
1993 \\
1993 \\
\end{array}$ & $\begin{array}{l}\text { Financial Services, } \\
\text { Telecom, Transporta- } \\
\text { tion, Media } \\
\text { Financial Services } \\
\text { Transportation } \\
\text { Financial Services } \\
\text { Not specified } \\
\text { Telecom } \\
\text { Financial Services } \\
\text { Not specified } \\
\text { Wholesale } \\
\end{array}$ & $\begin{array}{l}\text { Creating innovative climate } \\
\text { Creating innovative climate } \\
\text { Managing key activities } \\
\text { Managing key activities } \\
\text { Creating innovative climate } \\
\text { Managing key activities } \\
\text { Managing key activities } \\
\text { Managing key activities }\end{array}$ \\
\hline $\begin{array}{l}\text { European Journal of } \\
\text { Innovation Man- } \\
\text { agement }\end{array}$ & $\begin{array}{l}\text { Kandampully } \\
\text { Fernandez } \\
\text { Chryssochoidis \& Wong } \\
\text { Martin et al. }\end{array}$ & $\begin{array}{l}2002 \\
2001 \\
2000 \\
1999\end{array}$ & $\begin{array}{l}\text { Conceptual paper } \\
\text { Hospital } \\
\text { Financial Services } \\
\text { Business-to-Consumer } \\
\text { services }\end{array}$ & $\begin{array}{l}\text { Creating innovative climate } \\
\text { Managing key activities } \\
\text { Managing key activities } \\
\text { Creating innovative climate }\end{array}$ \\
\hline $\begin{array}{l}\text { Service Industries } \\
\text { Journal }\end{array}$ & $\begin{array}{l}\text { Vermeulen \& Dankbaar } \\
\text { McCabe } \\
\text { Chan et al. }\end{array}$ & $\begin{array}{l}2002 \\
2000 \\
1998\end{array}$ & $\begin{array}{l}\text { Financial Services } \\
\text { Financial Services } \\
\text { Financial Services, } \\
\text { Hotels \& Restaurants, } \\
\text { Tourism, Retail \& } \\
\text { Wholesale }\end{array}$ & $\begin{array}{l}\text { Managing key activities } \\
\text { Creating innovative climate } \\
\text { Managing key activities }\end{array}$ \\
\hline & Sundbo & 1997 & $\begin{array}{l}\text { Financial Services, } \\
\text { Tourism, Consultancy }\end{array}$ & Creating innovative climate \\
\hline & $\begin{array}{l}\text { Storey \& Easingwood } \\
\text { Thwaites \& Edgett }\end{array}$ & $\begin{array}{l}1993 \\
1991\end{array}$ & $\begin{array}{l}\text { Financial Services } \\
\text { Financial Services }\end{array}$ & $\begin{array}{l}\text { Managing key activities } \\
\text { Creating innovative climate }\end{array}$ \\
\hline $\begin{array}{l}\text { Journal of Services } \\
\text { Marketing }\end{array}$ & $\begin{array}{l}\text { Alam \& Perry } \\
\text { Edgett }\end{array}$ & $\begin{array}{l}2002 \\
1994 \\
\end{array}$ & $\begin{array}{l}\text { Financial Services } \\
\text { Financial Services }\end{array}$ & $\begin{array}{l}\text { Creating innovative climate } \\
\text { Managing key activities }\end{array}$ \\
\hline
\end{tabular}




\begin{tabular}{|c|c|c|c|c|}
\hline & $\begin{array}{l}\text { Scheuing \& Johnson } \\
\text { Bowers }\end{array}$ & $\begin{array}{l}1989 \\
1989\end{array}$ & $\begin{array}{l}\text { Conceptual paper } \\
\text { Financial Services, } \\
\text { hospitals }\end{array}$ & $\begin{array}{l}\text { Managing key activities } \\
\text { Managing key activities }\end{array}$ \\
\hline $\begin{array}{l}\text { European Journal of } \\
\text { Marketing }\end{array}$ & $\begin{array}{l}\text { Lievens \& Moenaert } \\
\text { Johne \& Storey }\end{array}$ & $\begin{array}{l}2000 \\
1998 \\
\end{array}$ & $\begin{array}{l}\text { Financial Services } \\
\text { Literature review }\end{array}$ & Creating innovative climate \\
\hline $\begin{array}{l}\text { Journal of Market- } \\
\text { ing Management }\end{array}$ & $\begin{array}{l}\text { Edgett \& Jones } \\
\text { Scarbrough \& Lannon }\end{array}$ & $\begin{array}{l}1991 \\
1989 \\
\end{array}$ & $\begin{array}{l}\text { Financial Services } \\
\text { Financial Services } \\
\end{array}$ & $\begin{array}{l}\text { Managing key activities } \\
\text { Creating innovative climate }\end{array}$ \\
\hline \multicolumn{5}{|l|}{ Other Journals } \\
\hline $\begin{array}{l}\text { Long Range Plan- } \\
\text { ning }\end{array}$ & Drew & 1995 & Financial Services & Creating innovative climate \\
\hline $\begin{array}{l}\text { Industrial Marketing } \\
\text { Management }\end{array}$ & Edgett & 1996 & Financial Services & Managing key activities \\
\hline $\begin{array}{l}\text { Journal of Manage- } \\
\text { ment Studies }\end{array}$ & Lievens \& Moenaert & 2000 & Financial Services & Creating innovative climate \\
\hline Bankers Magazine & Bortree & 1991 & Financial Services & Creating innovative climate \\
\hline$R \& D$ Management & Van Dijk \& van den Ende & 2002 & Telecom & Managing key activities \\
\hline Management Review & Terrill & 1992 & Conceptual paper & Creating innovative climate \\
\hline $\begin{array}{l}\text { Scandinavian Man- } \\
\text { agement Review }\end{array}$ & Van der Aa \& Elfring & 2002 & $\begin{array}{l}\text { Teleshopping, car } \\
\text { rental, hairstyling, } \\
\text { home furnishing, cater- } \\
\text { ing, professional clean- } \\
\text { ing, engineering, logis- } \\
\text { tic services, wholesale }\end{array}$ & Creating innovative climate \\
\hline
\end{tabular}

\begin{tabular}{lllll}
\hline $\begin{array}{l}\text { Management \& Or- } \\
\text { ganisatie (Dutch } \\
\text { Journal) }\end{array}$ & De Jong \& Kemp & 2001 & & Creating innovative climate \\
\hline Books \& Reports & & & & \\
\hline & De Jong et al. & 2002 & Literature review & Creating innovative climate \\
\hline Vermeulen & 2001 & Financial Services & Creating innovative climate \\
\hline Van der Aa & 2000 & $\begin{array}{l}\text { Consumer services, } \\
\text { Knowledge-intensive } \\
\text { business services, pro- } \\
\text { fessional services }\end{array}$ & Creating innovative climate \\
& & & Not specified & Creating innovative climate \\
\hline Edvardsson et al. & 2000 & Not specified & Creating innovative climate \\
\hline Cooper \& Edgett & 1999 & 1998 & $\begin{array}{l}\text { Financial Services, } \\
\text { Tourism, Consultancy }\end{array}$ & Creating innovative climate \\
\hline Sundbo & 1998 & Conceptual & Creating innovative climate \\
\hline
\end{tabular}

Table 1 Studies that focus on the organization of NSD (1988-2002) 
Stage 1: managing key activities

\begin{tabular}{|ll|}
\hline \multicolumn{2}{l|}{ People } \\
- & Involvement of frontline-employees \\
- & Presence of product champions \\
- & Management support \\
Structure \\
$-\quad$ Funnel tools \\
$-\quad$ Multifunctional teams \\
$-\quad$ Availability of resources \\
$-\quad$ Pre-launch testing \\
- Market research and launch \\
\hline
\end{tabular}

Stage 2: creating an innovative climate

\begin{tabular}{|ll|}
\hline \multicolumn{2}{l}{ People } \\
- & External contacts \\
- & Sharing information \\
- & Autonomy of employees \\
- & Strategic focus \\
- & Training and education \\
- & Internal organizations and task rotation \\
- & Information technology \\
\hline
\end{tabular}

(Innovation process)

$$
\rightarrow \text { Implementation }
$$

$\rightarrow$ Initiation \& Implementation

Figure 2 Two evolutionary stages of better organizing NSD: an overview organizational characteristics and their connection to the innovation process 